\title{
Argumentation Skill Profile of Students Using Android-Based E-Module on Chemical Equilibrium Topic
}

\author{
Muhamad Al Rasyid ${ }^{1}$ and Crys Fajar Partana ${ }^{2}$ \\ \{muhamad0006pasca.2019@student.uny.ac.id ${ }^{1}$, fajar_partana@uny.ac.id² $\}$ \\ Master of Chemistry Education, Faculty of Mathematics and Natural Sciences, Universitas Negeri \\ Yogyakarta, Indonesia ${ }^{1}$ Department of Chemistry Education, Faculty of Mathematics and Natural \\ Sciences, Universitas Negeri Yogyakarta, Indonesia ${ }^{2}$
}

\begin{abstract}
This study aimed to describe the argumentation skills profile of students at SMAN 1 Tanjungpinang. This research used a quantitative approach with descriptive statistical methods. The sample in this study consisted of 47 students as one group. The argumentation skill test had been carried out theoretical validation by two validators and empirical validation by thirty-six students. The questions consisted of 12 description questions that require students to make arguments by following the components of claims, evidence, and justifications. The results showed that students who were given treatment using an android-based e-module experienced an increase in the achievement of the argumentation components better than students who had not been given treatment
\end{abstract}

Keywords: Argumentation skill; Android-based e-module; Chemical equilibrium

\section{Introduction}

Education is a needed process to get balance and perfection in individual and community development. The emphasis of education compared to teaching lies in the formation of the consciousness and personality of the individual or society as well as the transfer of knowledge and expertise. Through this kind of process, a nation or state can pass on religious values, culture, thoughts, and expertise to the next generation so that they are truly ready to face a brighter future of the nation and state. Education is interrelated with the process of activities carried out by individuals to gain knowledge, instill attitudes, and develop skills to strengthen self-potential that must be possessed as an individual being or as a social being [1][2].

The proper education creates competent and quality human resources. Education serves to develop students' potential to be more confident, foster curiosity, be creative, innovative, and understand differences in the learning environment and community environment [3]. The quality of education in Indonesia is still low, this is due to low physical facilities [4]. Therefore, the media is needed as a means in the learning process to improve the quality of education. One of the media that can be used is technology based on the Android Operating System.

The development of technology in the 21st century give an impact on all aspects of life, including in the field of education. Technological developments require innovation in the use of technology in learning [5]. The necessity for the use of technology in the learning process is also enshrined in the 2013 curriculum so that educators and students as educational actors must be able to use technology as a practical and easy-to-use learning tool. The use of virtual learning 
media can improve the teaching system so that students become more active and the material delivered is more dynamic because it can be done anywhere and anytime [6].

Technology-based learning tools aid students in the learning process and can increase students' interest and motivation in learning [7]. The use of virtual reality learning media can make the learning process more interesting and able to motivate students to be more interactive, and subject matter is easier to understand, improve learning outcomes and make students motivated [8]. According to [9], the use of visual media can improve students' attitudes and interest during the learning process. Factly, nowadays Information and Communication Technology (ICT) have not been optimally utilized as a medium in the science learning process [10]. Related to efforts to increase the use of ICT in education, the use of e-modules is an alternative in the learning process.

E-module is a module based on Information and Communication Technology (ICT) have which has advantages over the print module including the interactive nature of the e-module which makes it easy in terms of material, display, use of software, images, video, audio, and animation and is equipped with formative quizzes that allow feedback. The e-module used in the learning process is equipped with interesting features as a flexible teaching unit for students which can improve students' literacy [11].

A virtual module is a form of presenting independent teaching materials arranged systematically and attractively equipped with animation, navigation, audio, which makes it easier for students to operate to achieve learning goals [12]. Therefore, it can be concluded that e-modules are media and sources used as interactive teaching materials that contain learning content, both core competencies, basic competencies, learning objectives, material summaries, questions, answer keys, reference sources, use of audio and visuals, and applying software. Frankly, there is still not the optimal use of e-modules (electronic modules) in the learning process [13].

Argumentation is an action taken by every individual in using logic and facts and making claims, evidence and evidence of a reasonable conclusion [14]. Argumentation was the process of getting arguments in a classroom learning that cannot be separated by carrying out a group discussion process between students where students will share ideas and exchange information so that the information obtained is durable [15]. In the process of arguing, students are allowed to build on the understanding they have and continuously develop their skills in argumentation [16]. Students were lacking in written argumentation skills during the learning process in class on elasticity and hooke's law [17].

Therefore, the importance thing is to conduct research to determine students' written argumentation skills in accordance with the aspects of correct argumentation skills, namely claims, evidence and justification.

Based on these elucidations; described the importance of education to create competent individuals in facing the rapid development of the globalization era, interesting innovations are needed, including the application of android-based e-modules to improve students' argumentation skills. The formulation of the problem in this study, namely.

a. What is the validity and reliability of the student argumentation skills measurement instrument?

b. What are the students' argumentation skills before and after being given treatment using an android-based e-module on chemical equilibrium material? 


\section{Methodology}

\subsection{Sample}

The sample in this study was class XI MIPA 2 with 39 students consisting of 23 women and 16 men and XI MIPA 3 which has 37 students consisting of 22 women and 15 men. Totally, 76 students. as a group. However, during the learning process online, only 47 students were consistent in answering the description questions both during the pre-test and post-test, therefore the data analyzed were data from 47 students.

\subsection{Data Collection Technique}

\section{Research Procedures}

This research was conducted by following several research procedures including:

a. Getting permission to the school.

b. Conducting interviews with chemistry teachers to know the students' argumentation skills during the chemistry learning process.

c. The first meeting began with the explanation of the research objectives, then carried out the distribution of questions about the students' description of argumentation skills.

d. Collecting pre-test data obtained.

e. The second and third meetings conducted a discussion and learning process using androidbased e-modules as a medium and learning resource.

f. The fourth meeting spreads the questions of argumentation skills descriptions to students.

g. Collecting post-test data obtained.

h. Analysing data collected with software aided.

\section{Interview}

Interviews were conducted with two chemistry teachers in class XI MIPA at SMA N 1 Tanjungpinang to find out the initial data about the students 'argumentation skills in the chemistry learning process. The interview instrument has been validated theoretically by three validators.

\section{Test}

The test technique was used to collect data and information before and after being given treatment in the form of e-modules in the learning process. The data in the test technique were descriptive questions, the essay questions used in the research process consist of 12 questions, 6 pre-test questions and 6 post-test questions. Problem description used theoretical and empirical validation processes have been carried out.

\section{Instruments and Data Analysis}

The instrument in this study was the interview guide which aims to determine the initial analysis of the research sample and the description questions which aim to measure the students' argumentation skills in the learning process. The data that has been collected was then described using statistical descriptive methods with the help of the quest program, SPSS version 23 and Microsoft Excel. 


\section{Result and Discussion}

In an effort to obtain valid research results, the instruments used in the study need to be checked for validity and reliability. The validation of the interview guidelines has been carried out theoretically by 3 validators, while the validation of description questions has been carried out theoretically and empirically. The theoretical validation was carried out by 5 validators and empirical validation was carried out on 36 students. This aimed to identify and evaluate the instruments that will be used in the research. Based on the results of theoretical validation, the interview guidelines for description questions were declared valid. Suggestions and input from the validator related to the theoretical validation of the description questions, are shown in table 1.

\subsection{Results of Theoretical Validation}

Table 1. The Results of Suggestions and Inputs Validation Question Description

\begin{tabular}{|c|c|}
\hline Validator & Suggestions \\
\hline \multirow[t]{2}{*}{$1^{\text {st }}$ Validator } & Revise word editorial \\
\hline & $\begin{array}{l}\text { Take a look at the chemical compounds in the } \\
\text { problem descriptions number } 4,10 \text { and } 12\end{array}$ \\
\hline \multirow[t]{2}{*}{$2^{\text {nd }}$ Validator } & $\begin{array}{l}\text { It is necessary to pay close attention to the items in } \\
\text { the description }\end{array}$ \\
\hline & $\begin{array}{l}\text { It is necessary to have an observation sheet to } \\
\text { measure the argumentation skills of students }\end{array}$ \\
\hline $3^{\text {rd }}$ Validator & $\begin{array}{l}\text { Revise sentence editorial explaining the sentence of } \\
\text { the question }\end{array}$ \\
\hline $4^{\text {th }}$ Validator & Revise the equivalent of words to make it standard \\
\hline \multirow[t]{3}{*}{$5^{\text {th }}$ Validator } & Coefficients do not need to be specified \\
\hline & $\begin{array}{l}\text { Pay attention to writing the equilibrium constant } \\
\text { notation }\end{array}$ \\
\hline & Writing formulas follow the specified conditions \\
\hline
\end{tabular}

Based on Table 1 the revised theoretical validation results were corrected then empirical validation was carried out on 36 students from SMAN 1 Singkep Barat and SMAN 1 Tanjungpinang. The school was determined due to the availability of students in responding to the question instruments that were distributed. The efforts to determine the validity of each item in the description used the quest program guided by the MNSQ infit value range, namely 0.77 $\leq X \leq 1.30$ [18]. The results of empirical validation of description questions using the Quest program are shown in Table 2.

\subsection{Empirical Validation Results}

Table 2. Results of Validation Question Description

\begin{tabular}{ll}
\hline Validity value & Questionnaire Item Number \\
$<0,77$ & 5,10 \\
$0,77 \leq \mathrm{X} \leq 1,30$ & $1,2,3,4,6,7,8,9,11,12,13,14,15$ \\
$>1,30$ & - \\
\hline
\end{tabular}

Based on Table 2, it showed that the items in the MNSQ infit $0.77 \leq X \leq 1.30$ are declared valid, while those outside $0.77 \leq \mathrm{X} \leq 1.30$ are declared invalid questions. Description questions 
that do not meet the valid criteria are questions number 5 and 10 . The results of the reliability test of the essay questions have a Alpha Cronbach value of 0.71 meaning that the reliability is in the good category. So that the other 13 items in the description meet the criteria of valid and reliable and suitable for use. However, in the study only 12 descriptive questions were used, because there was one question that had almost the same shape.

\subsection{Results of Preliminary Analysis}

Before conducting the research, the researcher conducted interviews with the chemistry teacher regarding the argumentation skills of students in the chemistry learning process, especially in the chemical equilibrium sub-material. Based on the results of interviews conducted with chemistry teachers at SMAN 1 Tanjungpinang, it was found that students had argued but the arguments given were not structured and were not in accordance with the aspects of argumentation skills.

Students have not shown the ability to claim answers according to the questions given and have not been optimal in providing justification for the answers they get. The results of the interview are relevant to the literature study which states that the argumentation skills of students are still not optimal and not yet structured. Therefore, it becomes a reinforcing factor for researchers to know and describe the argumentation skills of students in the learning process before and after using android-based e-modules.

\subsection{Pre-test Results}

The research process that has been carried out in which students are asked to answer questions in writing in accordance with the specified aspect of argumentation skills. The procedure of this pre-test activity was the researcher thanks the students online, then the researcher explained the purpose of the research carried out and the students are able to take part in the learning process. Then the researchers distributed description questions to students to be answered according to their abilities. The means to find out the argumentation skills of students before and after using android-based e-modules on chemical equilibrium material can be seen in Figure 1.

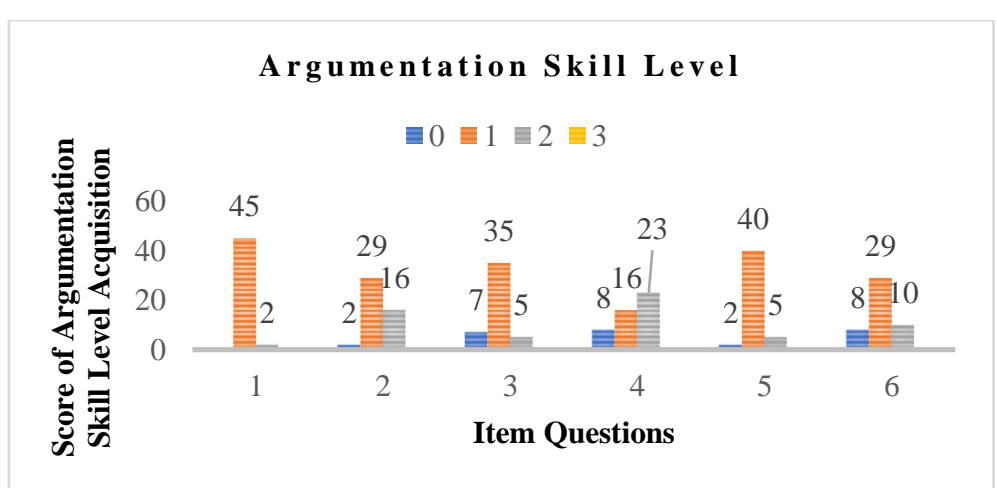

Fig 1. Score Acquisition of Argumentation Skills Level Before Treatment

Based on Figure 1, it is known that the results of the acquisition of argumentation skill level scores from 47 students before being given treatment in detail are explained as follows: question number 1, 45 students answered level 1, 2 students answered level 2 . Then for question number 2, 2 students answered level 0, 29 students answered level 1 and 16 students answered level 2. 
Figure 1 also obtained information, namely question number 3, 7 students answered level 0, students who answered level 1 and 5 students who answered level 2. Based on question number 4, 8 students answered level 0 , there were 16 students who answered level 1 and there were 23 students who answered level 2. Then question number 5 there were 2 students who answered level 0 , there were 40 students who answered level 1 and there were 5 students who answered level 2. Then the last one was question number 6 that 8 students answered level 0, 29 students answered level 1 and there were 10 students who answered level 2.

Based on Figure 1, that the argumentation skills of students are still low because they are more dominated by answers with level 1, namely students are able to argue, but aspects of the argument (claims, evidence and justification) are still inaccurate. When did the pre-test, the students have not shown their ability to argue because students did not know how to argue correctly, because students argued but were not structured, according to [19], each student had the most frequent debates in their arguments in solving unstructured problems?

Factors that affect the low argumentation skills of students were caused by the lack of students knowing the concept of learning material and aspects of the correct argumentation. Based on the results of the interview at the analysis with the chemistry teacher, in fact that students were still not skilled in arguing correctly, especially that students had not been given treatment that was able to stimulate their argumentation skills. The class that had not been given treatment had lower argumentation writing performance than the class that was given treatment [20].

The results of the research stated that students who have not been given treatment using the integrated electronic module-assisted inquiry model have a lower value than the class that has been given treatment [21]. The conceptual understanding of the control class students is lower than the experimental class because the experimental class has been treated using an optical device using android [22].

\subsection{Post-test Results}

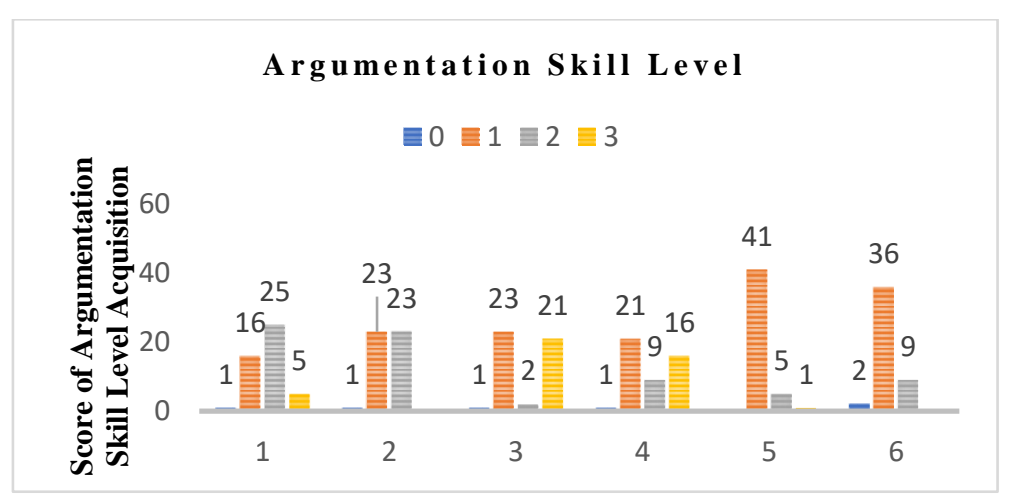

Fig 2. Scores for the Acquisition of Argumentation Skills Level Before Treatment

Based on Figure 2, it is known that the results of the acquisition of scores from 47 students after being given treatment are described in detail as follows: question number 1, there is 1 student who answered with level 0, 16 students answered level 1, there are 25 students answered level 2 and There were 5 students who answered level 3 . Then for question number 2, there was 1 student who answered level 0, 23 students answered level 1 and 23 students answered level 2. Based on the picture presented that question number 3 it is known that there is 1 student who 
answered level 0, 23 students who answered level 1, 2 students who answered level 2 and 21 students who answered with level 3 . Then question number 4 contained 1 student who answered level 0,21 students who answered level 1,9 students answered level 2 and 16 students answered level 3. Question number 5 found 41 students answered b level 1, 5 students answered level 2 and 1 student answered level 3. Then for question number 6, 2 students answered level 0 , there were 36 students who answered with level 1 and there were 9 students who answered level 2.

Based on Figure 2, that the students' argumentation skills have experienced development where the answers with level 1 dominate, but the ability of students who answer the description questions with level 2 and level 3 has been achieved. Based on Figure 1 and Figure 2, the students' argumentation skills can be seen at each level have changed. Level 0 at the time of the pre-test 8 students did not provide claims, evidence and justification, then decreased at the time of the post-test to 2 students. Level 2 at the time of the pre-test 16 students did not provide claims, evidence and justification appropriately, then increased at the time of the post-test to 23 students. Level 3 at the time of the pre-test there were no students who gave claims, evidence and justification as a whole and precisely, then increased at the time of the post-test to 21 students.

Based on the results that have been described that the acquisition of the argumentation skill level of students at the post-test has increased at level 0, level 2 and level 3. Factors that cause an increase in the acquisition of the argumentation skill level of students include students being able to use the android-based e-module where anytime and anywhere according to the time they want. In line with research conducted it is the implementation of learning using Android can be used anywhere and anytime [23]. Then another factor is the material in the e-module contains a systematic summary and provides sample questions to develop students' argumentation skills. That the use of web modules has an influence on the thinking skills of students in the experimental class and control class in the learning process [24].

In line with research learning using e-modules has an impact on student achievement [25]. Then the results obtained by the researchers were also supported by the research of that the use of a digital integrated practicum module has an influence on the motivation of students in the learning process [26]. The use of technology-based applications is able to facilitate students in learning activities and have a positive influence on learning achievement and learning experience of students [27]. The use of technology which is used as multimedia learning has a positive impact, such as students understand the material presented and learning activities become more interesting [28].

\section{Conclusions and Suggestions}

\subsection{Conclusions}

Based on the results and discussion that has been presented, it is known that the instrument of measuring argumentation skills is declared theoretically valid by expert lecturers. Then declared valid and reliable based on the results of empirical validation to 36 students. The students 'argumentation skill profile before being given treatment using an android-based emodule on chemical equilibrium material is below $50 \%$ of students have not shown their skills in arguing according to the aspects measured. After being given treatment using an androidbased e-module on chemical equilibrium material, the argumentation skills of students had increased at several levels of argumentation skills, namely at level 2 and level 3 becoming better.

Therefore, the students 'argumentation skills of students after being given an androidbased e-module on chemical equilibrium material are better than the argumentation skills of the participants before being given an android-based e-module on chemical equilibrium material. 


\subsection{Suggestions}

For researchers who will conduct similar research, the suggestions given to further researchers are expected to further examine the effect of android-based e-modules by using a longer research time and make an effort to conduct direct meetings to find out what percentage of students use e-modules.

\section{Acknowledgments}

The authors would like to acknowledge the students, teachers, validators and schools involved in the data gathering for their help. Authors are also thankful to Master of Chemistry Education, Faculty of Mathematics and Natural Sciences, Universitas Negeri Yogyakarta, Indonesia for their help.

\section{References}

[1] Nurkholis, "Pendidikan dalam upaya memajukan teknologi Oleh: Nurkholis Doktor Ilmu Pendidikan, Alumnus Universitas Negeri Jakarta Dosen Luar Biasa Jurusan Tarbiyah STAIN Purwokerto," vol. 1, no. 1, pp. 24-44, 2013.

[2] S. Saat, "Faktor-faktor determinan dalam pendidikan (studi tentang makna dan kedudukannya dalam pendidikan)," J. Ta'dib, vol. 8, no. 2, pp. 1-17, 2015, [Online]. Available: ejournal.iainkendari.ac.id/al-tadib/article/view/407.

[3] E. Ersoy and N. Başer, "The effects of problem-based learning method in higher education on creative thinking," Procedia - Soc. Behav. Sci., vol. 116, pp. 3494-3498, 2014, doi: 10.1016/j.sbspro.2014.01.790.

[4] H. Widodo, "Potret pendidikan di Indonesia dan kesiapannya dalam menghadapi masyarakat ekonomi asia (Mea)," Cendekia J. Educ. Soc., vol. 13, no. 2, p. 293, 2016, doi: 10.21154/cendekia.v13i2.250.

[5] N. Özdener and F. Demirci, "Determining students' views about an educational game-based mobile application supported with sensors," Technol. Knowl. Learn., vol. 24, no. 1, pp. 143-159, 2019, doi: 10.1007/s10758-018-9368-x.

[6] I. M. Suarsana and G. A. Mahayukti, "Pengembangan e-modul berorientasi pemecahan masalah untuk meningkatkan keterampilan berpikir kritis mahasiswa," J. Nas. Pendidik. Tek. Inform., vol. 2, no. 3, p. 193, 2013, doi: 10.23887/janapati.v2i3.9800.

[7] I. Akman and C. Turhan, "Male and female differences in the use of social media for learning purposes," Innov. Educ. Teach. Int., vol. 55, no. 5, pp. 543-553, 2018, doi: 10.1080/14703297.2017.1407250.

[8] O. A. Meyer, M. K. Omdahl, and G. Makransky, "Investigating the effect of pre-training when learning through immersive virtual reality and video: A media and methods experiment," Comput. Educ., vol. 140, no. December 2018, p. 103603, 2019, doi: 10.1016/j.compedu.2019.103603.

[9] S. Turkoguz, "Research and practice learn to teach chemistry using visual media tools," 2012, doi: 10.1039/c2rp20046e.

[10] B. Sumintono, "Penggunaan TIK dalam pengajaran: Survey pada guru-guru sains smp di Indonesia," J. Pengajaran MIPA, vol. 17, no. 1, pp. 14-15, 2012.

[11] F. S. Irwansyah, I. Lubab, I. Farida, and M. A. Ramdhani, "Designing interactive electronic module in chemistry lessons," J. Phys. Conf. Ser., vol. 895, no. 1, 2017, doi: 10.1088/17426596/895/1/012009.

[12] D. Sugianto, A. G. Abdullah, S. Elvyanti, and Y. Muladi, "Modul virtual : multimedia flipbook dasar teknik digital," INVOTEC, vol. IX, no. 2, pp. 101-116, 2013.

[13] Purwaningtyas, W. D. Dwiyogo, and I. Hariyadi, "Pengembangan modul elektronik mata pelajaran pendidikan jasmani, olahraga, dan kesehatan kelas xi berbasis online dengan program edmodo," J. Pendidik., vol. 2, no. 1, pp. 121-129, 2017. 
[14] A. Kat Cooper and M. T. Oliver-Hoyo, "Argument construction in understanding noncovalent interactions: A comparison of two argumentation frameworks," Chem. Educ. Res. Pract., vol. 17, no. 4, pp. 1006-1018, 2016, doi: 10.1039/c6rp00109b.

[15] D. Karışan, Ö. Yılmaz Tüzün, and D. L. Zeidler, "Quality of preservice teachers argumentation in socioscientific issues context," J. Hum. Sci., vol. 14, no. 4, p. 3504, 2017, doi: 10.14687/jhs.v14i4.4949.

[16] M. Karpudewan, W. Michael Roth, and D. Sinniah, "The role of green chemistry activities in fostering secondary school students' understanding of acid-base concepts and argumentation skills," Chem. Educ. Res. Pract., vol. 17, no. 4, pp. 893-901, 2016, doi: 10.1039/c6rp00079g.

[17] P. Handayani, Murniati, and S. S. M, "Analisis Argumentasi peserta didik kelas x sma Muhammadiyah 1 Palembang dengan menggunakan model argumentasi toulmin," J. Inov. dan Pembelajaran Fis., vol. 2, no. 1, pp. 60-68, 2015.

[18] R. J. Adams and S.-T. Khoo, "Acer Quest: The Interactive Test Analysis System,” Australian Council for Educational Research. 1998.

[19] L. Y. Sakinah, S. Kartiko, and S. Nas, "The effect analysis of self attitude and efficacy on entrepreneurship intention of economics education students, universitas riau," J. Educ. Sci., vol. 3, no. 3, p. 318, 2019, doi: 10.31258/jes.3.3.p.318-327.

[20] N. Ika Noviyanti, W. Rosyadah Mukti, I. Dahlia Yuliskurniawati, S. Mahanal, and S. Zubaidah, "Students' scientific argumentation skills based on differences in academic ability," J. Phys. Conf. Ser., vol. 1241, no. 1, 2019, doi: 10.1088/1742-6596/1241/1/012034.

[21] G. Awada, J. Burston, and R. Ghannage, "Effect of student team achievement division through WebQuest on EFL students' argumentative writing skills and their instructors' perceptions," Comput. Assist. Lang. Learn., vol. 33, no. 3, pp. 275-300, 2020, doi: 10.1080/09588221.2018.1558254.

[22] N. R. Hariani and M. Nuswowati, "Pengaruh penerapan model inkuiri terbimbing berbantuan e-modul terhadap pemahaman konsep hidrolisis garam," J. Inov. Pendidik. Kim., vol. 14, no. 1, pp. 25612571, 2020.

[23] O. A. Nanda and I. Wilujeng, "The effectiveness of android-assisted optical devices learning to improve students' conceptual understanding," J. Penelit. dan Pembelajaran IPA, vol. 4, no. 2, p. 105, 2018, doi: 10.30870/jppi.v4i2.4038.

[24] A. S. Putri and N. Aznam, "The effect of the science web module integrated on batik's local potential towards students' critical thinking and problem solving (thinking skill)," J. Sci. Learn., vol. 2, no. 3, pp. 92-96, 2019, doi: 10.17509/jsl.v2i3.16843.

[25] K. R. Winatha and M. M. Abubakar, "The usage effectivity of project-based interactive e-module in improving students' achievement,” J. Pendidik. Teknol. dan Kejuru., vol. 24, no. 2, pp. 198-202, 2018, doi: 10.21831/jptk.v24i2.20001.

[26] N. Harefa and L. Sanga Lamsari Purba, "The development of chemistry practicum e-module based on simple-practice," J. Pendidik. Kim., vol. 11, no. 3, pp. 107-115, 2019, doi: 10.24114/jpkim.v11i3.15739.

[27] D. P. French, "Self-efficacy and health," Int. Encycl. Soc. Behav. Sci. Second Ed., vol. 23, no. 4, pp. 509-514, 2015, doi: 10.1016/B978-0-08-097086-8.14123-6.

[28] K. F. Maker and L. Motivation, "E-module development using kvisoft flipbook maker through," J. Educ. Sci., vol. 4, no. 4, pp. 834-848, 2020. 